\title{
Macrogenitosomia Praecox Due to an Interstitial Cell Tumour of the Testis
}

\author{
E. C. ALLIBONE, C. K. ANDERSON, and M. W. ARTHURTON \\ From the General Infirmary, Leeds; and the Children's Hospital, Bradford
}

An interstitial cell tumour of the testis produces a characteristic clinical picture. Starting between the ages of 2 and 6 years, the boy develops macrogenitosomia praecox with a raised excretion of urinary 17-ketosteroids. The tumour, which is usually unilateral and non-malignant, may not be obvious initially. Occasionally there is gynaecomastia. Penile erections are frequent. The behaviour ranges from normality, through increased aggressiveness, to embarrassing sexual precocity. The differential diagnosis is from virilizing adrenal hyperplasia. 39 cases have been reported (Johnstone, 1967).

The following case was treated as one of adrenal virilism for a year before the correct diagnosis was made.

\section{Case Report}

This boy was born in 1949 weighing $3.3 \mathrm{~kg}$. His voice had always been deep since beginning to talk. He was of a muscular type. Rapid genital development was noticed at 2 years, but advice was not sought until the age of $4 \frac{3}{4}$ years. Over the previous year there had been penile erections and possibly emissions.

Examination showed an abnormally muscular looking boy, height $118 \mathrm{~cm}$., span width $116 \mathrm{~cm}$. Pubic hair present. Length of penis $8.7 \mathrm{~cm}$. and circumference $8 \mathrm{~cm}$. Both testes felt normal for his age. Bone age 11 years. With a urinary output of $500-600 \mathrm{ml}$. per day the 17-ketosteroid excretion ranged between $3 \cdot 6$ mg. and $5.6 \mathrm{mg} . / 24 \mathrm{hr}$. Serum Na was $138 \mathrm{mEq} / 1$., $\mathrm{K} 4.4 \mathrm{mEq} / 1$, and $\mathrm{Cl} 94 \mathrm{mEq} / 1$.

A diagnosis of adrenal virilism was made. Treatment was started with oral cortisone $25 \mathrm{mg}$. daily.

Over the next year his parents thought he improved in that he 'looked younger'. No regression, however, occurred in the secondary sex characteristics (Fig. 1), in the urinary 17-ketosteroid excretion (Fig. 2), or in the skeletal maturation (Fig. 3). At no time was his behaviour abnormal.

Fifteen months later, at the age of 6 years, he had 2 nocturnal emissions within a period of 6 weeks, and this led to reassessment. The right testis was now

Received June 10, 1968. found to be larger and firmer than the left (right $2.5 \times$ $2.0 \mathrm{~cm}$., left $2 \cdot 0 \times 1.25 \mathrm{~cm}$.).

Urinary oestrogens, none detected at a level of 60 I.U. per day; urinary gonadotrophins, none detected at a level of 20 mouse units per day.

A biopsy of the right testis was reported (Dr T. W. Sutherland): 'The section shows tumour cells, arranged sometimes loosely, sometimes in rounded compact nodules, in a moderately vascular stroma. The tumour cells, mostly rounded or polygonal, have abundant, eosinophilic, granular cytoplasm, sometimes vacuolated. Crystalloids and brown pigment seem absent. The nuclei, with sharply defined nuclear membranes, are hyperchromic. Mitoses cannot be detected, but occasional tumour cells are bi-nucleate. Variation in size of cells and nuclei is pronounced' (Fig. 4).

Right orchidectomy followed. On section a wellencapsulated mass $4 \times 3 \mathrm{~mm}$. was situated within the testis (Fig. 5), which histologically showed a dense mass of tumour tissue compressing well-formed seminiferous tubules, in which there was no spermatogenesis. The cellular pattern of the growth was in all respects similar to that seen in the biopsy. On morphological grounds it was considered to be an interstitial cell tumour of the testis.

After the orchidectomy there was a drop in the level of the urinary 17-ketosteroid excretion, but it never reached normal figures and subsequently kept at a level slightly higher than normal (Fig. 2).

The bone age now advanced at the normal rate; from a level of 13 years at the time of his operation (at the age of 6), it advanced 5 years in the following 6 years, so that he had reached a bone age of 18 years at a chronological age of 12 years, at which age he reached his final height of $155 \mathrm{~cm}$. (Fig. 3).

\section{Discussion}

The differential diagnosis of testicular tumours in association with macrogenitosomia praecox lies between an interstitial or Leydig cell tumour and an adrenal rest in congenital adrenocortical hyperplasia. Some writers maintain it is not possible to distinguish histologically between the two conditions (Hedinger, 1954; Schoen, Di Raimondo, and Dominguez, 1961). The latter workers could not reach a decision in their case, even after studying 


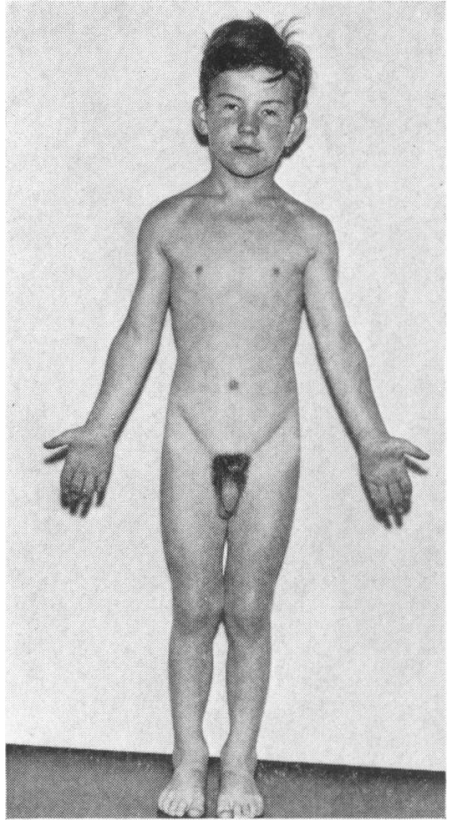

FIG. 1.-The patient aged 6 years. Appearance after one year's treatment with cortisone.

the secretory activity of the tumour and the results of tissue incubation.

Congenital adrenal hyperplasia is an autosomal recessive phenomenon, with an incidence of 1 in 40,000 births. The first case in a family is often

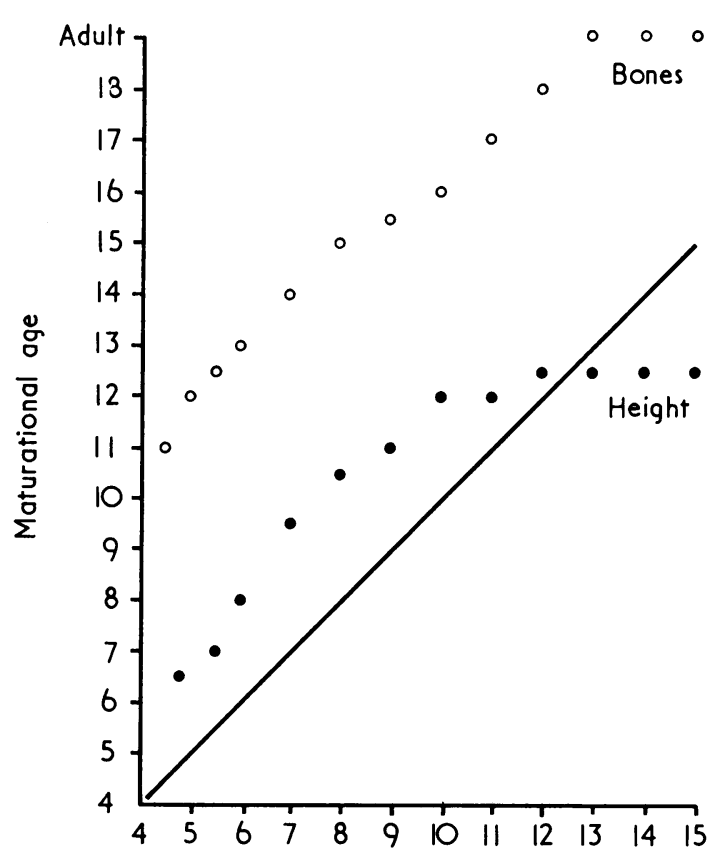

Chronological age (years)

FIg. 3.-The relation of height age and bone age to chronological age.

missed. A death in infancy of a male sib with a history of persistent vomiting would be suggestive; a sib with intersex would be even more so.

Leydig cell tumours are rare. Some writers have

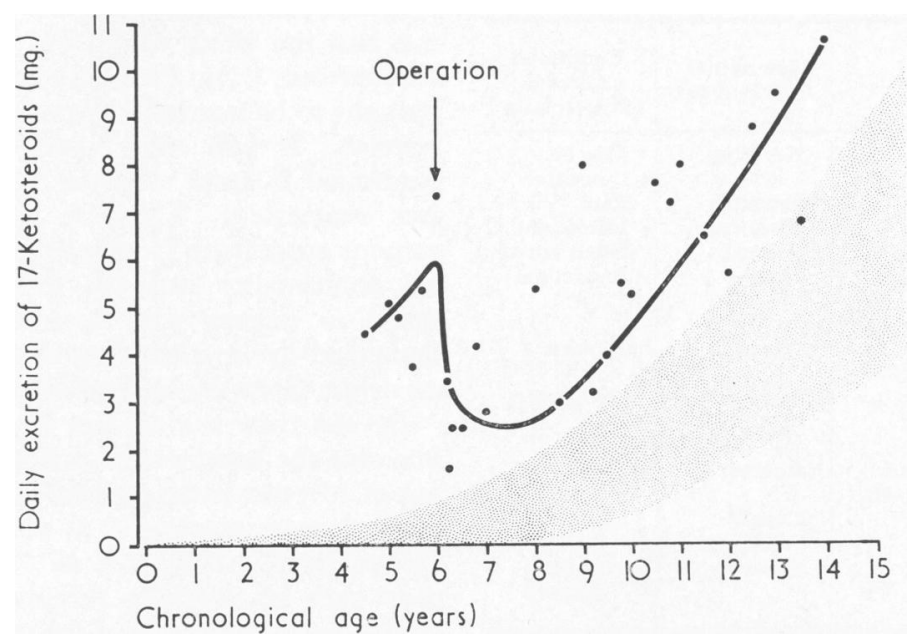

Fig. 2.-24-hour urinary 17-ketosteroid excretion. Range of normal values shown by shaded area (Talbot et al., 1943). 


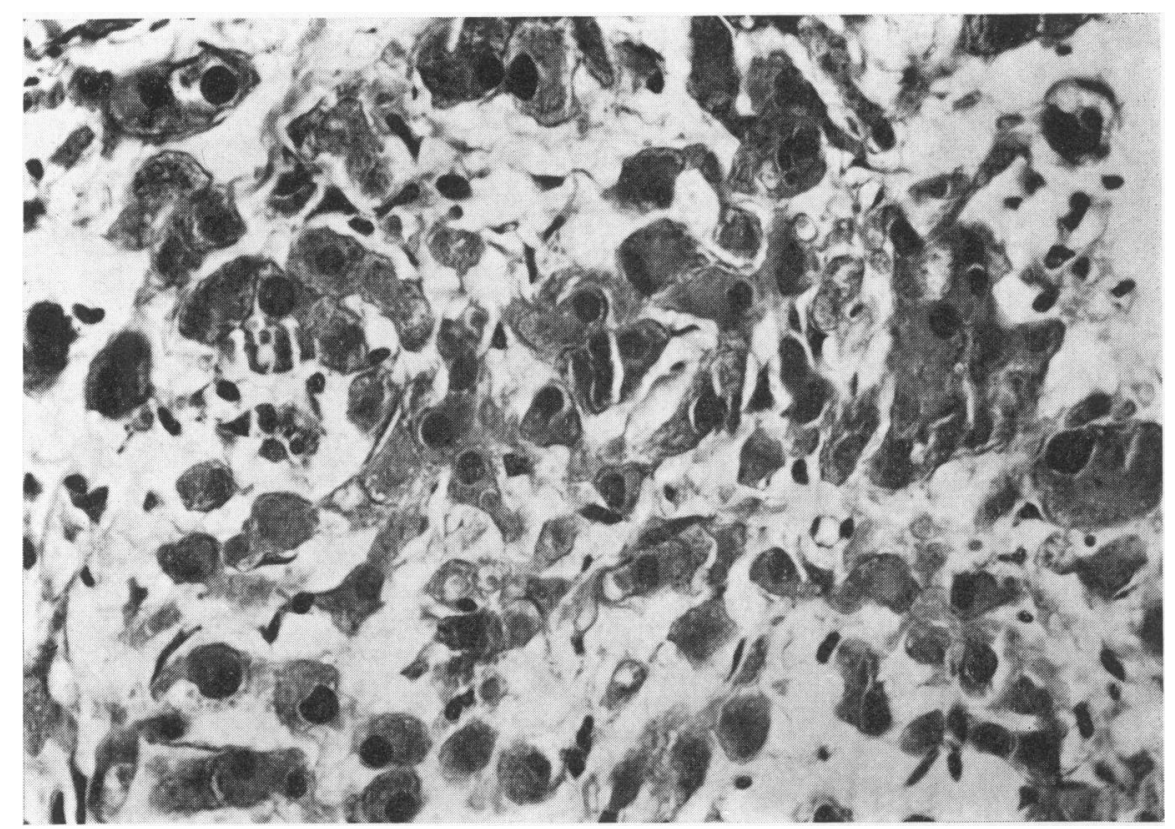

FIG. 4.-Cellular pattern of the tumour. (H. and E. $\times 225$.

gone so far as to say that most virilizing testicular tumours derive from adrenal rests in congenital adrenal hyperplasia (Glenn and Boyce, 1963).

TABLE

Comparison Between Interstitial Cell Tumour of Testis and Testicular Adrenal Rest in Congenital Adrenal Hyperplasia

\begin{tabular}{|c|c|c|}
\hline & $\begin{array}{l}\text { Interstitial } \\
\text { Cell Tumour }\end{array}$ & $\begin{array}{c}\text { Congenital } \\
\text { Adrenal } \\
\text { Hyperplasia }\end{array}$ \\
\hline Family history & Negative & $\begin{array}{l}\text { May be } \\
\text { positive }\end{array}$ \\
\hline $\begin{array}{l}\text { Nocturnal emissions } \\
\text { Precocious sexual behaviour } \\
\text { Urinary salt excretion } \\
\text { Effect of cortisone therapy on } \\
\text { urinary 17-ketosteroid } \\
\text { excretion }\end{array}$ & $\begin{array}{l}\text { Frequent } \\
\text { Frequent } \\
\text { Normal } \\
\text { None }\end{array}$ & $\begin{array}{l}\text { Rare } \\
\text { Infrequent } \\
\text { Often raised } \\
\text { Reduction }\end{array}$ \\
\hline $\begin{array}{l}\text { Effect of ACTH on urinary } \\
\text { 17-ketosteroid excretion }\end{array}$ & Increase & Increase \\
\hline $\begin{array}{l}\text { Effect of ACTH on urinary } \\
\text { 17-hydroxycorticosteroid } \\
\text { excretion }\end{array}$ & Increase & No increase \\
\hline $\begin{array}{l}\text { Abnormal urinary metabolites } \\
\text { (pregnanetriol, tetrahydro-S) }\end{array}$ & Absent & Present \\
\hline Laterality of tumour & $\begin{array}{l}\text { Usually } \\
\text { unilateral }\end{array}$ & $\begin{array}{l}\text { May be } \\
\text { bilateral }\end{array}$ \\
\hline $\begin{array}{l}\text { Effect of steroid therapy on } \\
\text { size of tumour }\end{array}$ & None & $\begin{array}{l}\text { May be } \\
\text { reduced }\end{array}$ \\
\hline
\end{tabular}

$\star 2$ out of 32 reported cases of interstitial cell tumour were bilateral (Camin et al., 1960).
As such adrenal rests should regress when treated with steroids (Hedinger, 1954; Prader, 1953), Glenn and Boyce suggested that steroid therapy should be tried in all such cases. The differentiating points between the two conditions are summarized in the Table.

In the case described there was no family history of adrenal hyperplasia, nor was there salt loss. Pregnanetriol determinations were not available nor had the effect of ACTH on these cases been worked out. On the other hand, the testes were thought to be normal in size and the behaviour was normal. It was only when nocturnal emissions continued in spite of steroid therapy that the case was reassessed. There is little doubt that the tumour arose from Leydig cells, since the biochemical abnormality and the growth of the tumour failed to regress with steroid therapy. Further, the naked-eye and histological appearance suggested an origin from the interstitial cells of the testis.

By the time the correct diagnosis was made in our case the bone maturation had reached a critical age of 13 years when skeletal maturation and androgenic output continued at a rate consistent with his bone age. Savard et al. (1960), in considering their case of virilizing tumour of the testis, concluded that irrespective of the true chronological age, some relation existed between the level of somatic 


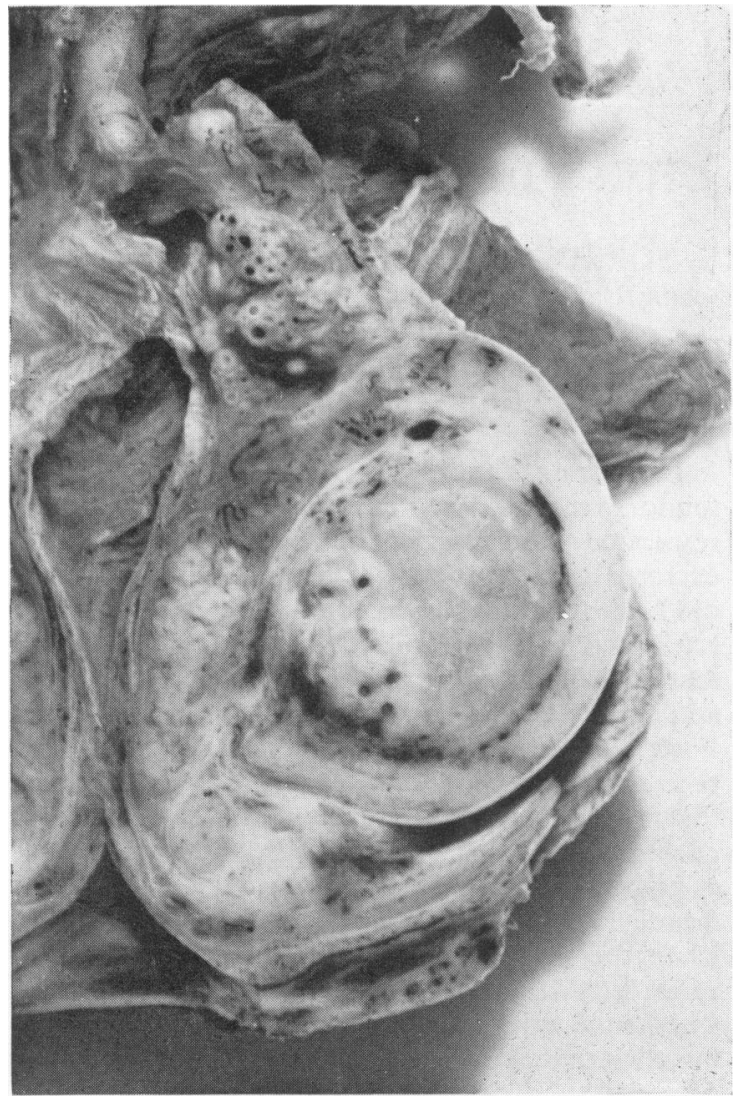

FIG. 5.-Cut surface of testis showing encapsulated tumour.

and skeletal development and the initiation of the hypothalamic-pituitary discharge which led to the elaboration of gonadotrophin. Martin, Canary, and Balsamo (1962) also argued that, as the ultimate height attained by a child with a virilizing tumour was somewhat dependent upon the height he had attained by the time his bone age had reached 12 or 13 years, it was important for these tumours to be removed before the bone age had advanced too far: premature closure of the epiphyses otherwise ultimately led to short stature.

\section{Summary}

A case of macrogenitosomia praecox due to a solitary interstitial cell tumour of the testis was thought initially to be due to virilizing adrenal hyperplasia. After a year the diagnosis was corrected and confirmed histologically.

The differentional diagnosis of interstitial cell tumours of the testis is summarized.

We are indebted to Dr. T. W. Sutherland for his histological reports; to the University of Leeds Department of Medical Illustration for the graphs; and to the Photographic Departments of the General Infirmary and St. James's Hospital, Leeds, for photographs.

REFERENCES

Camin, A. J., Dorfman, R. I., McDonald, J. H., and Rosenthal, I. M. (1960). Interstitial cell tumour of the testis in a sevenyear-old child. Amer. F. Dis. Child., 100, 389.

Glenn, J. F, and Boyce, W. H. (1963). Adrenogenitalism with testicular adrenal rests simulating interstitial cell tumor. f. Urol. (Baltimore), 89, 456.

Hedinger, C. (1954). Beidseitige Hodentumoren und kongenitales adrenogenitales Syndrom. Schweiz. Z. allg. Path., 17, 743.

Johnstone, G. (1967). Prepubertal gynaecomastia in association with an interstitial-cell tumour of the testis. Brit. F. Urol., $39,211$.

Martin, M. M., Canary, J. J., and Balsamo, P. A. (1962). Virilizing tumor of the testis in one twin. F. clin. Endocr., 22, 345.

Prader, A. (1953). Die Cortisondauerbehandlung des kongenitalen adrenogenitalen Syndroms. Helv. paediat. Acta, 8, 386.

Savard, K., Dorfman, R. I., Baggett, B., Fielding, L. L., Engel, L. L., McPherson, H. T., Lister, L. M., Johnson, D. S., Hamblen, E. C., and Engel, F. L. (1960). Clinical, morphologi$\mathrm{cal}$ and biochemical studies of a virilizing tumor in the testis. f. clin. Invest., 39, 534.

Schoen, E. J. Di Raimondo, V., and Dominguez, O. V. (1961) Bilateral testicular tumors complicating congenital adrenocortical hyperplasia. $\mathcal{F}$. clin. Endocr., 21, 518 .

Talbot, N. B., Butler, A. M., Berman, R. A., Rodriguez, P. M. and MacLachlan, E. A. (1943). Excretion of 17-keto steroids by normal and by abnormal children. Amer. f. Dis. Child., $65,364$. 